\title{
The curious relationship between agricultural and en- ergy price index: A Vector Error Correction Model (VECM) analysis approach
}

\author{
Vicente E. Montaño ${ }^{1 *}$, Rosalia T. Gabronino ${ }^{2}$, Restie E. Torres ${ }^{3}$ \\ 1, 2, 3 University of Mindanao, Davao City, Philippines
}

\section{Keywords \\ Price index \\ VEC analysis \\ Global}

Received: 7 January 2019

Accepted: 15 April 2019

Published: 28 June 2019

\begin{abstract}
The primary purpose of this study is to examine the relationship between monthly energy and agriculture price indices. The research uses the Vector Error Correction Model (VECM) methods, taking into account the cointegrating relationship among the series of monthly observations from October 1973 to October 2018. Contrary to the findings of earlier studies, the empirical result of this research indicates that the oil price index responds to the equilibrium between agriculture and oil, and that is, the agricultural price index affects the energy price index and not the other way around. This study attempted to quantify the causal relationship between energy and agricultural price using the structural economic framework that recognized the fundamental problem in the relationship between energy and agriculture. Furthermore, this study presented a window of opportunity to closely examine the curious relationship between energy and agriculture prices.
\end{abstract}

(C) 2019 The Author(s). Published by TAF Publishing.

\section{INTRODUCTION}

In October 1973, the first oil price shock jolted the energy market, exposing the vulnerability of industrialized countries' energy market which heavily dependent on oil. American policymakers realized that event outside their borders could significantly shape the energy security (Horwich \& Weimer, 1984). To reduce dependency on oil, an interagency analysis under the Carter Administration recommended that renewable energy can supply 20 percent of the US energy requirement by the year 2000 (Sovacool, 2009). However, in 2013 renewable energy accounted for only 12 percent of the overall energy supply (Dhillon \& von Wuehlisch, 2013). The continued increase in the price of oil during the W. Bush administration led to a considerable development of renewable energy production. However, oil still dominates 82 percent of the total energy consumption (Hale \& Nechio, 2012; Yoshino \& Alekhina, 2016).

Moreover, the oil price increase affects the rise of agriculture commodity prices. The world-oil price shock on agriculture has an economy-wide repercussion traceable to the direct and indirect cost link between energy and the agriculture sector (Hanson, Robinson, \& Schluter, 1991). Consequently, a rise in oil prices brings higher agricultural commodity prices (Nazlioglu \& Soytas, 2012). The increasing reliance on industrial economies on biofuels strengthened the relationship between oil and agricultural prices. Relatively the rising oil prices and favorable renewable energy policies expanded biofuel production created a declining food stock. Thus, the already tight market environment created the condition for the rapid food price increase in 2007 and 2008 (Trostle, 2010). The United States since 1906 has already pursued an energy policy favorable to the production and utilization of renewable energy (Kovarik \& Singh, 2013). Specifically, the US government policy made ethanol, a derivate from corn, the singular gasoline additive available to US refineries starting May 2006 (Elobeid \& Tokgoz, 2006). The increasing demand for the production and use of ethanol accounted for 21 percent and 22 percent increase in price for rice and wheat (Cheamuangphan, Singhavara, \& Phaoumnuaywit, 2018; Rosegrant, 2008). Other indus-

* corresponding author: Vicente E. Montaño

†email: jvicente_montano@umindanao.edu.ph 
trialized countries in European Union adopted a policy of increasing their biofuel target from 5.75 percent to 10 percent, which they supplemented with ethanol imports from the US and Latin America (Sorda, Banse, \& Kemfert, 2010). This study intended to generally examine the evidence that linked energy prices to agriculture prices, although several studies previously raised the issue. Also, this study aims to contribute to the growing literature that used timeseries data to investigate the relationship between energy prices and agriculture commodity prices. A most recent investigation concluded that an increase in oil prices consequently increase prices of agriculture commodities. These studies relied much on cost-push inflation to explain such phenomena (Gohin \& Chantret, 2010; Esmaeili \& Shokoohi, 2011; Nazlioglu \& Soytas, 2012). However, several studies challenge the causality of oil prices to food prices instead suggested causality in the other direction (Avalos, 2014; Baumeister \& Kilian, 2014).

Agriculture products are grouped into five commodities food, beverage, vegetable oils, and meals, other grains, agricultural raw materials, other raw materials (Bond, 1987). The food group is composed of the major cereals (rice, wheat, maize, barley, millet, and sorghum) (Bevan \& Murphy, 1999). The beverage is coffee, cocoa, and tea (Labys \& Perrin, 1976), while the vegetable oil and meals contained soybeans oil and meals, palm oil, coconut oil, and ground oil (Gunstone, 2011). The composition of the other foods is sugar, bananas, beef, chicken, and oranges (Pfaffenzeller, Newbold, \& Rayner, 2007). Also, agricultural raw materials are timber, log, and sawn woods, while other raw materials are cotton, natural rubber, and tobacco (World Bank, 2016). Meanwhile, coal, crude oil, and natural gas composed the energy commodity (Arezki, Loungani, van der Ploeg, \& Venables, 2014; Khakimyanov \& Khusainov, 2016).

\section{Objectives of the Study}

This study attempted to quantify the causal relationship between energy and agricultural price using the structural economic framework that recognized the fundamental problem in the relationship between energy and agriculture. The objective of this study is to contribute to the growing investigation that the price of agriculture affected the price of energy and not the other way around.

\section{LITERATURE REVIEW}

The Literature Review of this study started in October 1973, the beginning of oil price volatility, which corresponded to the appearance of a new regime in the global market (Baumeister \& Kilian, 2016). Since 1973, the prices of oil increased fourfold in a matter of a single year, driving oilimporting countries to impose economic control that resulted in crisis (Alier, 2009).

\section{The 1970s}

Since 1973 prices of cereals showed similar routes in terms of sudden price increase, including the shape of increase and decrease. They are primarily traced to a poor harvest, decreasing stocks and unfavorable world trade (Joerin \& Joerin, 2013). During 1973, in the US, agricultural exports, consumption decreased significantly than the production share (Popkin, 1974).

The unknown causes for the erratic price movement in 1973 were attributed to speculation or inflation-hedging demand for commodities. The problem arose in June 1973 when the US imposed a price ceiling on commodities. The US decision to embargo exports of soybeans encountered massive adverse reactions on the price of agricultural products worldwide, drawing supplies of agrarian products from the American market (Cooper, Lawrence, Bosworth, \& Houthakker, 1975). Specifically, in Bangladesh, it was the price bubbles in rice due to excessive speculation and not oil, which resulted in the 1974 famine (Quddus, Becker, et al., 2000). Likewise, the agricultural price increase in 1973 was attributable not to the increase in oil price but the rise in land prices, causing a multi-dimensional effect of inflation on capital deterioration. Consequently, farmland price swings affect returns to farming further creating credit market constraints (Just \& Miranowski, 1993).

In 1977, the increased farm expense raised prices of coffee, seafood, and corn, soybeans, and wheat and non-farm items (New York Times, 1977). Also, the price of both agricultural and forestry land increased to almost 37 percent in less than a year. Such an increase was attributed to the demand for better quality land (Barrett \& Trace, 1999).

In a span of five years, 1972 to 1977 , land prices in the US increased 5.6 percent per year compared to the average annual general price increase of 7.1 percent. In 1973 and 1974 , the high commodity prices provided farmers enough cash and incentives to buy additional land. Due to the internal and external elements, changes in world politics, monetary situation, and climate repeatedly undermine income causes the price of land to increase beyond the inflation rate (Gardner, Nuckton, et al., 1979).

The changes in industrial production among developed countries significantly influence the price of agricultural raw materials. The primary energy issue confronting US agriculture during this period was price-related more than supply related. The impacts of energy price increase were 
on inflation and economic growth rates rather than on energy-based farm inputs (Carter \& Youde, 1974). An empirical investigation suggested that food prices would increase not more than 1 percent even if petroleum prices rose by 50 percent. Indeed, energy price increase did not directly result in agriculture production cost increase (Whittlesey \& Lee, 1975). Moreover, the reduced proteinrich animal feed in 1974 created pressure for the increased substitution of soybean meal for animal feeds (Butz, 1974) in response to the growing world's market demand of red meat (Box, 1974). Comparable to other major industries, agriculture has a 24 percent minimal share of energy consumption. To a large extent, modern agricultural technology demands energy-intensive inputs such as pesticide, machinery, and fertilizers (Stout, Stout, Myers, Hurand, \& Faidley, 1979). The annual incremental growth in agriculture production is attributed to the increased use of energyintensive inputs such as 8 percent increase in fertilizer use, 10 to 30 percent demand higher than the supply of pesticide, and 5.9 percent increase in mechanization (Food and Agriculture Organization, 1973). However, the rising energy prices in the 1970s, limited energy supplies, and increasing awareness paved growing interest to adopt new and old technologies that save and adjust energy use in agriculture production practices (Miranowski, 1979).

For the first time in almost 30 years, world energy consumption decreased in 1974. Total energy consumption declined by 3 percent, and oil consumption decreased by 3.2 percent. At the same time, farmers in many countries started to adopt less intensive but less productive techniques. During the first half of 1975, the high commodity prices in 1974 induced farmers to reduce inputs and change cropping patterns. Among developing countries, the high population growth rate exerted pressure to increase agriculture production.

The effect of energy price increases on the production of three major crops by small growers on the Island of Hawaii proved that higher energy costs have not significantly affected the net revenues of small growers. Net revenues appear to be relatively inelastic to the changes in energy costs, indicating that an increase in energy price did not uniformly affect small growers. An essential part in defining the effect of energy price on the agrarian output was traceable from the mix of labor and cost, which demonstrated that farms confront several constraints that limited factor substitution (Gopalakrishnan, Koffi-Tessio, \& Khaleghi, 1985).

\section{The 1980s}

Major grain-producing countries wanted to increase their market share and started providing farmers repayment terms, financing and subsidies which eventually become the agriculture sector standard (Bergsten \& Cline, 1982). During the same period, the world price increase of fertilizer was not directly attributable to the oil price increase (Lockeretz, 1983). At the start of the 1980s, U.S. farmers and policymakers expected that agriculture export would continue to grow. Thus, there was an increase in the demand for machinery and land to improve production and increase profit. The agriculture policy was still directed for full production, anticipating a strong export market to absorb the grain surplus (Drabenstott, 1983). Despite the full production policy, food prices increased in 1980 attributed to the low global food prospect (Brown, 1982). Later, government assistance to farmers of several developed countries ceased which resulted in low agricultural productions (Wik, Pingali, \& Brocai, 2008).

Developing countries' significant growth in income and population increase the demand for US agriculture exports (Longmire \& Morey, 1983). With the dollar devaluation, centrally planned economies find it cheaper to import US grains than to produce, gradually shifted from a net food exporter to net importer (Johnson, 1981). Similarly, oilproducing countries concentrate on petroleum production at the expense of agriculture, while other developing countries demand grains for livestock feeding (Johnson, 1981). These changes in the world's agricultural scenario generated radical changes in US agrarian policies.

In the early 1980s the Federal Reserve Board increase the interest rate to reduce the rate of inflation as a consequence the cost of farming increased, farmers often cannot find a loan even to finance their operations (Harl, 1985). Many farmers debt increases forced the government to reduce farm support (Latruffe \& Le Mouël, 2009). Consequently, marginal farmers sold their land, and the average size of farms increased. Also, loaned money financed the increase in the farm output, increasing the total farm debt to $\$ 216$ billion in 1983 (Harl, 1985).

In the 1980s, FAO reported that food production slightly increased due to the rate of growth in fertilizer use was still below the utilization rate in the 1970s. Since the use of fertilizer contributed to a 50 percent increase in production, the decline in fertilizer use in the 1980s (Food and Agriculture Organization, 1983a), caused world grain stock to fall in 1981, below the minimum level of safety set for the world food security. In particular, the Philippines' decline in fertilizer importation the opportunity loss in grain 
yields was ten times the cost of fertilizer importation (David \& Balisacan, 1982). Moreover, recorded in the 1980s was China's highest sustained fertilizer use together with other centrally planned economies in Asia. Nonetheless, domestic food price inflation continues to accelerate significantly affecting these low food-deficit income countries by more than 10 percent (Fan, 2019).

Investment in small-scale irrigation works improves price incentives. As a result, an observed 20 percent increase in fertilizer used in short-season or dry seasons of rice crops (Fleischer \& Stibe, 1989). Aside from increasing use of fertilizers and pesticide, development projects focused on crop rehabilitation, irrigation construction facilities, and technical-capacity assistance. Also, fertilizer consumption per hectare increased support plans to improve fertilizer use in small farm holdings (Binswanger, 1989).

Generally, because of rising energy prices, farmers bought fewer fertilizers and machinery but more labor, reversing previous trends of reducing labor inputs. The changes decreased farm outputs (D. Christensen \& Heady, 1984). These economic forces significantly shaped the energy used in agriculture. The latest agricultural technology improved productivity as energy directly substituted inputs. The situation created an environment that brought research towards increasing the productivity and substitutability of energy in agriculture (Heady, 1984). Technology discovered during the period such as capital, machinery, and fertilizer reduces cost in labor and energy (Adelaja \& Hoque, 1986). Since the technology used in agricultural production among the biggest cereal exporters in the world was almost entirely mechanized, they easily accommodate energy price increase without a significant increase in food prices (Watt, 1984).

The early 1980s marked the end of low energy price period which has a significant effect on agriculture. The energy crisis exposed the limitations and weaknesses of agriculture policies. For the first time, during the early 1980s, fertilizer production was less than consumption due to the impact of the acreage-reduction program in the US. Due to weak demand, prices of fertilizer continued to decrease (Talbot \& Moyer, 1987). However, in the middle of 1983 demand for fertilizer picked up as the market stabilized and strengthened the price increase of cereals. As a result in late 1983, farmers increased the areas planted precursory to the increased fertilizer use until the middle of 1984. Notably in Asia during the late-1983 weather conditions were favorable to grow crops increased the use of fertilizer until the end of 1984 (Abedin, 1985).

In developed countries, mechanization in agriculture sig- nificantly remodeled farming. Through the introduction of new technologies such as the harvester, grain combines, and tractors increased farm size and crop yields (Schmitz \& Moss, 2015). However, for most countries in Africa, small and fragmented fields become an obstacle to mechanization; in contrast, it was a different scenario in Asia and Latin America. Farmers persist in adopting mechanized farming. Most developing economies in the 1980s experienced a crisis when the Agreement on Agriculture under World Trade Organization (WTO) initiated reforms through the external liberalization of agriculture. The increased trade flows did not bring closer price uniformity between developing economies and advanced economies (Bello, 2008). The policy shifts from emerging and developed economies were asymmetric demonstrating that their agriculture was complementary rather than competitive. For instance, Thailand Bath depreciated 30 percent against the US dollar to maintain the competitiveness of Thai exports in consonance to trade reforms, which encouraged the greater use of fertilizers and pesticides (Thapinta \& Hudak, 2000).

Aggravating the position of developing economies were the protectionist measures which constrained the expansion of their export to service debts (Felix, 1985). Further, the deep recession weakened the agricultural commodity prices in the international market, contract competition in agrarian trade, and reduced the development assistance to rural development of developing economies (Chaudhuri, 1986). The increase in agricultural prices in late 1982 through 1983 was the effect of the terms-of-trade. In the first half of 1983, barter terms of trade between agrarian products and crude oil increased by 12 percent and as much as 30 percent in developing market economies (Food and Agriculture Organization, 1983a). Moreover, decreasing export earnings and rising balance of payment deficit reduced the capacity of the non-oil exporting countries to sustain food imports (Krugman, 1983).

The existing economic condition dampened developing countries' exports in a period when the trade deficit was unusually large (Edwards, 1989). Significantly, the slow growth in agricultural product demand was an emerging trend. The trend did not provide developing countries incentives to increase production for export and consumption (Hazell, Jaramillo, \& Williamson, 1990). The discouraging economic environment and international price increase along with decreased available food aid increased the additional burden on developing countries (Clay \& Benson, 1990).

The slow increase in exports and domestic demand resulted in a poor prospect for agriculture-based growth in 
1988. The poor prospective growth raised protectionism and increase inflation, which forced the government to increase interest rates resulting in slow economic growth (Binswanger, 1989). Production of petroleum decreased, and external debt increased to record levels (Sharma \& Singer, 1989). Low oil price posed a threat to developing countries' agriculture growth which increases demand for cotton, jute and natural rubber with the sustained oversupply of agricultural commodities reduced exports (Food and Agriculture Organization, 1983b).

For other Asian nations, changing oil and non-oil commodity prices were the main determinants of merchandise trade performance. Generally, weak oil prices hurt exporters but helped importers (Soesastro, 1989). Price increases for such agricultural raw materials as jute, timber, and rubber helped several exporter countries, especially during 1987-88. Prices of most minerals and metals also rose, though less rapidly. Prices of food commodities, mainly rice, were low until late 1987, and tropical beverage prices were also generally weak (Food and Agriculture Organization, 1983b). There was a steady decrease in the output of cereal production (Akanni \& Okeowo, 2011).

The threat of higher consumer prices for developing economies appeared more substantial, which resulted in too much faith in the effectiveness of agricultural prices to produce output responsive to the market, reduce reliance on government budget to finance agricultural inputs and service. The developing country's foreign exchange shortages reduced their ability to import new inputs, which are energy-intensive. Such limited capacity-cut total production (Alderman \& Von Braun, 1986).

In 1983, the world economy slowly recovered from a deep recession, which significantly affected agriculture. But the condition of developing economies remains uncertain since the international interest rate remained high, worsening debt burden situation (Massad, 1986). Due to the decreasing farm income, several farmers' organizations exerted pressures for government assistance. Consequently, a significant increase in agricultural prices in 1981 caused the US to introduce the program that reduced cereal stocks (Cathie, 1985), increase prices, and lower production cost (Bullock, 1984). The decrease in oil prices and the corresponding increase in interest rates worsened the debt situation of developing countries, further deteriorating growth projections (Singer, 1989). A significant international price increase made a downturn in the food security market situation in 1987 and 88. The global surplus situation in some essential agricultural commodity markets turned to relative scarcity (Kloos, 1991).
During the same period, there was a sharp increase in food emergencies incidence where 31 states confront food shortages caused by natural and human-made calamities (Talbot \& Moyer, 1987). Notably, in Africa, drought increased the number of refugees in an alarming proportion. The continuing inflation in food prices, freight handling costs, and a meager 2 percent increase in volumes of food commodities over 1970-1980 was the primary cause in the deterioration of food aid (Shipton, 1990).

Recurring droughts and floods, including political instability, severely reduced food and agricultural production in several countries and added to the increasing regional food shortages. Low agrarian prices and profitability channeled resources away from agriculture resulting in increasing inequality between agricultural and non-agricultural incomes and forced production increases (Wilhite \& Glantz, 1985). Notably, food commodity prices increase 17.7 percent, whereas the aggregate price index of selected 33 commodities excluding oil increase to almost 13 percent. The extended drought in North America and product policy change are the reasons for the declining world agricultural commodities supply (Food and Agriculture Organization, 1983b).

\section{The 1990s}

Notably, in 1995, global agricultural production declined, the US crops and livestock production decreased by 8 percent, attributed to adverse weather, while output in European Union continued the decreasing trend in production for few years. Similarly, the Russian Federation, Ukraine, and Kazakstan continued to experience a decline in agricultural production attributed to drought (Meshcherskaya \& Blazhevich, 1997). During the same period, the Agricultural sector in Latin America generally performed poorly. In Mexico, Cuba, Central America, agricultural production stagnated and even declined. Also, drought slowed output to 1.7 percent in Near East and North Africa (Halila, Haddad, Sakr, \& Küsmenoglu, 2000). Likewise, in Jordan production decreased by 5 percent and abysmal production in Libya, Saudi Arabia and Tunisia (Food and Agriculture Organization, 1995). In the Far East and Pacific agricultural production growth significantly slowed to 1.8 percent lower than the population growth due to catastrophic floods (D'Ercole \& Pigeon, 1998).

Major factors in the overall increase in energy and agriculture were the overall index, which contributed to nearly 40 percent in the consumer price increase. The unusually cold winter in the US and Europe combined with a low stock of oil led to the increase of price compared to the 1990 Gulf 
War which caused energy prices an 8.6 percent increase. The US Energy Department attributed the price increase to the February, March, and April late cold weather (Wilson, 1997).

The dismal performance of the agricultural sector resulted in acute food shortages among 26 countries, which required emergency food assistance. Also, during the same year, global cereal stock decreased for the last three years. Thus, these conditions resulted in a grain price increase to record levels in 1995 attributed to production shortfall, low stock level and strong export demand (Food and Agriculture Organization, 1995).

The result of the cereal and corn shortfall, decreasing low stock (Khush, 1999), and an increasing demand cause grain prices to increase (C. Christensen, 2000). Comparatively, in the last five months of 1996, the market observed rice prices (Hart \& Babcock, 2000) as a result of decreasing demand from Bangladesh, China, and Indonesia.

During the 90s, researchers were starting to focus on the production of biomass as another source of energy (Hanegraaf, Biewinga, et al., 1998). The most promising energy from biomass during the period was the by-products from the production of feed, fiber, and food as a source of low-quality biomass (Lunnan, 1997). Although the future position of biofuel in the 90s was uncertain, prospective analysis on future development proposed the developing countries as a supplier of biofuel for the European Union market (Cadenas \& Cabezudo, 1998). Part of the uncertainty in the US to adopt biofuel as an energy alternative in compliance to Ky oto protocol was the estimated energy cost increase which increases the production variable cost by 3 to 13 percent and decreased net return by 6 to 18 percent (Antle, Capalbo, Johnson, \& Miljkovic, 1999). Eventually, policymakers believed that as the energy price shock wore off, recovery would arrive, but the successive event proved that what was believed to be temporary energyprice distortion was permanent (Griliches, 1998).

During the 1990s, non-OPEC members' countries were far more efficient in producing more oil than members of OPEC. The non-members can bargain more effectively which makes the price of their oil more attractive (Ramcharran, 2002). In particular, Kuwait an OPEC member was producing oil more than its quota limit which led to the First Gulf War in 1990. OPEC frustratingly continued to set oil production quota to its members to keep price and production profitable, but to no avail (Karsh \& Rautsi, 1991).

In 1990 the Saddam Hussein's forces occupied Kuwait for seven months on the unproven ground that Kuwait was stealing oil reserves of Iraq, which led the US and its west- ern allies to protect their oil interest in the region. During the First Gulf War, a drastic reduction in oil production affected the oil price. In only three months, production decreased from 24 million barrels per day to 20 million, which increased the price from $\$ 17$ per barrel to $\$ 46$, a 270 percent increase in three months (Leech, 2006).

Decline in use of fertilizers from 148.29 million tons in 1990 to 147.62 million tons in 1999, 132 million tons in 1993 were the lowest consumption in the decade (Roser \& Ritchie, 2018). The continuous state of disequilibrium in the agriculture sector caused a decline in the use of fertilizer (Heisey \& Mwangi, 1997).

Generally, the energy-based inputs in agriculture, between 1990-1994 significantly decreased. For instance, deliveries of fertilizer decreased to 90 percent; farm machinery decreased by 80 percent; petroleum decreased 65 percent, and the production of machinery and pesticide decreased by over 80 percent. The decline posed serious effect in trying to promote agriculture recovery and growth during the 1990s (Sidhu \& Mudahar, 1999).

\section{The 2000s}

Before the 2000 energy crisis occurred in Northwest America, very few new power plants were built, though electricity demand continued to grow. Policymakers were aware of an impending energy crisis, but no hydro-power company wanted to invest in a power plant with no long term guaranteed contracts (Taylor \& VanDoren, 2002). The energy crisis was the result of the reduced hydro-power generation. In particular, California suffered an energy crisis in 2000 (Duane, 2002). The state used 80 percent of their water resources for agriculture purposes (Pollak, 2010). The California agriculture sector played an important role in the economy of the state, which includes contributions to transportation, food processing and exportation (McCouch et al., 2013). The vegetables, fruits, and nuts production continue to increase (Khan, Martin, \& Hardiman, 2003). During the same period, the demand for energy in agriculture increased (Lofman, Petersen, \& Bower, 2002).

Several multiple interacting factors that led to agricultural production decreased from 2003 to 2007 led eventually to a food crisis in 2008 (Asche, Khatun, et al., 2006; Karunagoda, 2004). The prolonged drought in Australia between 2005 and 2007 drastically reduced wheat production and trade (Anwar, O'Leary, McNeil, Hossain, \& Nelson, 2007).

Aside from the increasing income, several weather-related shocks drastically affected supply, which further explained the commodity price increase during the year (Conceição \& Mendoza, 2009). Indeed these shocks become more fre- 
quent in the succeeding years.

Industrialized countries formulated policies that promote the extensive use of biofuel in the industry which caused the increasing demand for corn and vegetable oil (Coalition et al., 2006), but at the same time created trade barriers such as tariff, subsidies and legislative use (Coelho, 2005). The depreciation of the US dollar changed some major trade policies of small countries, eventually affecting agricultural commodities (Shane \& Liefert, 2007).

Several factors caused the spike in agricultural commodity prices, such as the increasing demand for biofuels. However, there was difficulty in determining the exact contribution of biofuel to the widening demand for an agriculture price increase. Nonetheless, biofuel demand exerted pressure on agricultural prices (Nonhebel \& Kastner, 2011). The demand and supply of biofuel in succeeding years continued to increase. The increasing demand for biofuels was not the single factor that contributed to the price increase. Instead, it is the fast demand growth of biofuel that affected the food security, food prices and income (Nonhebel, 2012). Due to the emerging condition in agriculture as the result of expanding demand for biofuel and the subsequent result for a price increase of agricultural commodities, there was a growing return of agricultural investment, which attracted development assistance in the agricultural sector similar to the 1970s (Koizumi, 2013). As a consequence, was the growth of croplands in Europe, America, Asia and subSahara Africa. But in the short-run, this condition did not immediately translate to increased output (Aha \& Ayitey, 2017).

Partly, the low level of agricultural stocks was the result of government trade policies that did not help trade. Export bans and agriculture produce buying of the government encouraged producers to limit supplies resulted in traders increasing demand, and consumers resort to panic buying (Headey, 2011).

Certainly, the very low global grain stock in 2008, which was repeated in 2011 caused prices of agricultural commodities to significantly increase (De Gorter, Drabik, \& Just, 2015). Due to the repetitive supply shocks, some analysts recognized agricultural commodities were becoming a haven for investors (Jensen \& Mercer, 2011). While most countries suffered from low global grain stock, some large countries were able to protect themselves from the world market (Christiaensen, 2009). Remarkably, the actions of these countries increased world market price volatility aggravating the situation of some small countries more badly than otherwise possible if large countries did not raise trade barriers (Dethier \& Effenberger, 2011).
During the same period, several large emerging economies, Brazil, Russia, India, China, and South Africa (BRICS), experienced long-term resource-intensive economic growth exerted pressure on prices of fertilizers and petroleum (Sebri \& Ben-Salha, 2014). Millions enjoyed an increase in purchasing power which increased demand for meat, as living standards increased and diets diversified (Belardo, 2018). The scenario led to increasing production costs in agriculture and transport cost as a consequence of stronger demand for fertilizer and petroleum (Năstase, 2012). The increasing income and purchasing power in some developing countries played a major role in strong demand growth, which raised prices of agricultural commodities. The scenario and the macroeconomic environment become the cause of uncertainty in the agricultural market (Haq \& Meilke, 2009).

Similarly, low investment in cereal production over the past 20 years slowed growth in wheat and rice production. However, market demand for cereals increased due to portfolio diversification, and the speculation on commodity futures (Jokiniemi et al., 2012).

\section{The 2010s}

In July 2011, prices of agriculture commodities remained higher compared to the same period in 2010 and notably a food price index increase of 33 percent almost equal to the 2008 level. The price of grains such as corn, rice, and wheat prices remain high and uncertain due to low global stocks. In particular, corn has reached its lowest stock-to-use ratio of 13 percent since 1970 (Gustavsson, Cederberg, Sonesson, Van Otterdijk, \& Meybeck, 2011). The situation created a huge effect on price. The wide domestic price fluctuations of agriculture commodities in several developing countries were the result of the uncertainty of supply. The situation led to greater vulnerability, negatively impacting local populations (Streeten, 2016).

Seemingly, the price increase of rice, sugar, and petroleum posed an effect on the overall price movements. Although the price of crude oil in the second part of the year decreased, it remained volatile due to the uncertain political situation in the Middle East (Gustavsson et al., 2011). Also, Brazil's low sugarcane production caused the price of sugar to increase by 29 percent, further contributing to the volatility of the world's food prices. Finally, the unexpected increase in the price of rice added to the increase in price in agriculture commodities (Mohajan, 2013).

The continued increase in the prices of agricultural commodities significantly contributed to the inflation of several countries. Observably, in China, food price inflation regis- 
tered at 14.6 percent traced from the domestic producers of meat, fish, and vegetables. Moreover, food inflation was present in some Central American countries (Cachia, 2014). The decision of Russia to ban grain exports in July until the end of the year significantly reduced the world grain stocks. The drought reduced harvest in Kazakhstan, Russia, and Ukraine, which produces a quarter of the world's cereal production, while floods reduced US corn production to 3.4 percent (Götz, Glauben, \& Brümmer, 2013).

\section{RESEARCH METHODOLOGY}

The Engle-Granger method first generated residuals (errors) based on static regression, in which the Augmented Dickey-Fuller (ADF) was used to detect the presence of unit roots. If the time series are cointegrated, then the residuals will be practically stationary. A major issue with the EngleGranger method is that choice of the dependent variable may lead to different conclusions (Armstrong, 2002), an issue corrected by more recent tests such as Phillips-Ouliaris and Johansen's (Westelius, 2005).

The Johansen's VECM in this study inspects the long-term relations between the energy and agricultural price index. The VECM provides a full information maximum likelihood estimation model, in a single step can examine for cointegration in the equation without the need for normalizing a particular variable. The technique eliminates carrying over the error from the first to the second step, unlike the EngleGranger method. Also, VECM does not require a priori assumption of endogeneity or exogenity of the variables.

\section{RESULTS}

This study used the World Bank published data on the world's oil price index from October 1973 to October 2018.
This study used a VEC model because both energy and agriculture price index series are non-stationary in levels and differences, and the variables are integrated. Figure 1 showed the two-time series plot.

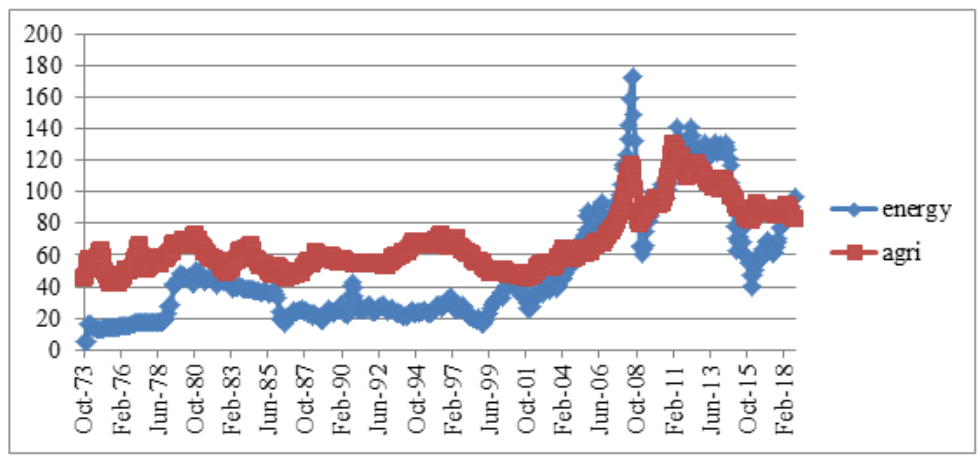

FIGURE 1. Institutional models for stability/changes of organizational practices

Both time series showed that neither is stationary in its level, and they demonstrate a common trend. Also, taking the difference of both series differences appeared as stationary and a possible presence of cointegration. The Dickey-Fuller regression estimate based on graphical information for levels with intercept, time trend and six (6) lags for oil price index, and two (2) lags for agriculture index. The augmented dickey-fuller test used the Schwert criteria which include 1 to $\mathrm{k}$ lags of the first, detrended energy index variable, where $k=18$ was set by the method (Schwert, 2002). Both energy and agricultural tau-statistics $(t$-statistics) $(-2.52$ and -2.70$)$ and both the normalized autocorrelation coefficient rejected the series were stationary at 0.05 confidence level. The result suggested that energy and agricultural index were not stationary.

TABLE 1. ADF test for energy and agriculture price index, october 1973 to october 2018

\begin{tabular}{lll}
\hline \hline & Energy Price Index & Agriculture Price Index \\
\hline Criteria & Schwert & Schwert \\
Drift & no & no \\
Trend & yes & yes \\
Lag & 18 & 18 \\
Alpha & 0.05 & 0.05 \\
Tau-stat & -2.52765 & -2.70745 \\
Tau-crit & -3.42013 & -3.42013 \\
Stationary & no & no \\
Akaike's Information Criterion (AIC) & 5.497582 & 3.993738 \\
Bayesian Information Criterion (BIC) & 5.569723 & 4.033588 \\
Lags & 6 & 2 \\
\hline \hline
\end{tabular}

The AIC (5.497 and 3.993) for both energy and agricultural price index, which were higher than 3 demonstrate that there was less support for the model (Anderson, Burnham, Anderson, \& Burnham, 1998; Wagenmakers, 2003). How- 
ever, the BIC (5.569 and 4.033) was between 2 and 6, which favored the model generated (Antle et al., 1999).
The Engle-Granger test of cointegration for agriculture price index ( $t=1.004, p=0.315)$ showed in Table 2 that it did not respond to the changes in the energy price index.

TABLE 2. Engle-Granger test of cointegration for the agriculture price index

\begin{tabular}{|c|c|c|c|c|c|c|c|c|}
\hline \multicolumn{9}{|l|}{$\begin{array}{l}\text { Regression } \\
\text { Statistics }\end{array}$} \\
\hline Multiple $R$ & 0.043237 & & & & & & & \\
\hline$R$ Square & 0.001869 & & & & & & & \\
\hline Adjusted $R$ & $1.42 \mathrm{E}-05$ & & & & & & & \\
\hline \multicolumn{9}{|l|}{ Square } \\
\hline Standard Error & 1.977737 & & & & & & & \\
\hline \multirow[t]{3}{*}{ Observations } & 540 & & & & & & & \\
\hline & $d f$ & $S S$ & $M S$ & $F$ & Significance & & & \\
\hline & & & & & $F$ & & & \\
\hline Regression & 1 & 3.948671 & 3.948671 & 1.009517215 & 0.315470206 & & & \\
\hline Residual & 5392108.269 & 3.911445 & & & & & & \\
\hline \multirow[t]{3}{*}{ Total } & 540 & 2112.217 & & & & & & \\
\hline & Coefficients & Standard & $t$-Stat & $p$-Value & Lower & Upper & Lower & Upper \\
\hline & & Error & & & $95 \%$ & $95 \%$ & $95.0 \%$ & $95.0 \%$ \\
\hline Intercept & 0 & & & & & & & \\
\hline $\begin{array}{l}\text { Energy price in- } \\
\text { dex }\end{array}$ & 0.003212 & 0.003197 & 1.004747 & 0.32 & -0.00306791 & 0.009492 & -0.00307 & 0.009492 \\
\hline
\end{tabular}

TABLE 3. Engle-Granger test of cointegration for the energy price index

\begin{tabular}{|c|c|c|c|c|c|c|c|c|}
\hline $\begin{array}{l}\text { Regression } \\
\text { Statistics }\end{array}$ & & & & & & & & \\
\hline Multiple $R$ & 0.096147 & & & & & & & \\
\hline$R$ Square & 0.009244 & & & & & & & \\
\hline Adjusted $R$ & 0.007389 & & & & & & & \\
\hline \multicolumn{9}{|l|}{ Square } \\
\hline Standard Error & 4.15449 & & & & & & & \\
\hline \multirow[t]{2}{*}{ Observations } & 4.15449 & & & & & & & \\
\hline & $d f$ & $S S$ & MS & $F$ & $\begin{array}{l}\text { Significance } \\
F\end{array}$ & & & \\
\hline Regression & 1 & 86.80098 & 86.80098 & 5.029087682 & 0.025331486 & & & \\
\hline Residual & 539 & 9303.025 & 17.25979 & & & & & \\
\hline \multirow[t]{3}{*}{ Total } & 540 & 9389.826 & & & & & & \\
\hline & Coefficients & Standard & $t$-Stat & $p$-Value & Lower & Upper & Lower & Upper \\
\hline & & Error & & & $95 \%$ & $95 \%$ & $95.0 \%$ & $95.0 \%$ \\
\hline Intercept & 0 & & & & & & & \\
\hline $\begin{array}{l}\text { Agriculture } \\
\text { price index }\end{array}$ & 0.01506 & 0.006716 & 2.242563 & 0.02533073 & 0.001868214 & 0.028252 & 0.001868 & 0.028252 \\
\hline
\end{tabular}

However, the Engle-Granger test of cointegration for energy index $(t=2.24, p=0.025)$ Table 3 exhibited that the energy index responds to the disequilibrium between energy and agriculture price. The result supports the idea that changes in the energy price depend on the changes in the agricultural price and not the other way around.

To get the VEC model results for energy price, the estimate regression reflected in Table 4 indicated that the significant negative coefficient on lag e showed that the energy price index responds to the disequilibrium between agriculture and energy price.

The residual test of normality reflected a non-normal distribution (JB $=73.26)$. The result was deemed a weakness in the robustness of the model. The residual nonnormality is not a serious problem; instead it demonstrated deviations from the long-term relationship between energy and agriculture prices (Górka, 2016). Admittedly, the nonnormality of the residual may be attributed to the ARCH effects since the price observation came from two economic sectors with different volatility (Lanne \& Lütkepohl, 2010). 
However, a structural VEC model assuming the non-normal distribution is beyond the scope of this study. The VECM de- veloped in this study has limitations that future researchers may consider.

TABLE 4. VEC model for the energy price index

\begin{tabular}{|c|c|c|c|c|c|c|c|c|}
\hline $\begin{array}{l}\text { Regression } \\
\text { Statistics }\end{array}$ & & & & & & & & \\
\hline Multiple $R$ & 0.895587 & & & & & & & \\
\hline$R$ Square & 0.802075 & & & & & & & \\
\hline Adjusted $R$ & 0.801708 & & & & & & & \\
\hline \multicolumn{9}{|l|}{ Square } \\
\hline Standard Error & 1.857079 & & & & & & & \\
\hline \multirow[t]{3}{*}{ Observations } & 540 & & & & & & & \\
\hline & $d f$ & $S S$ & $M S$ & $F$ & Significance & & & \\
\hline & & & & & $F$ & & & \\
\hline Regression & 1 & 7518.972 & 7518.972 & 2180.208 & $2.2 \mathrm{E}-191$ & & & \\
\hline Residual & 538 & 1855.423 & 3.448741 & & & & & \\
\hline \multirow[t]{3}{*}{ Total } & 539 & 9374.395 & & & & & & \\
\hline & Coefficients & Standard & $t$-Stat & $p$-Value & Lower & Upper & Lower & Upper \\
\hline & & Error & & & $95 \%$ & $95 \%$ & $95.0 \%$ & $95.0 \%$ \\
\hline Intercept & 0.067455 & 0.079946 & 0.843756 & 0.399181 & -0.08959 & 0.224498 & -0.08959 & 0.224498 \\
\hline Lag e & -0.92862 & 0.019888 & -46.6927 & 2.2E-191 & -0.96769 & -0.88956 & -0.96769 & -0.88956 \\
\hline
\end{tabular}

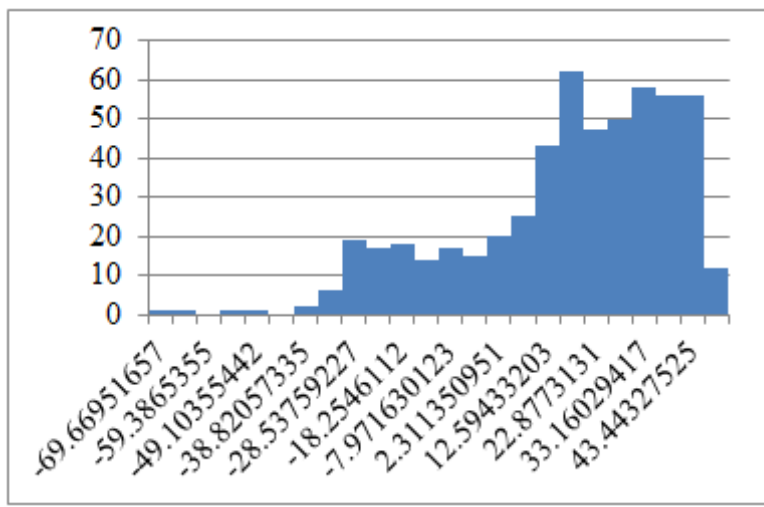

\begin{tabular}{|l|l|}
\hline Series & Residuals \\
\hline Observation & 542 \\
\hline Mean & 14.5417 \\
\hline Median & 18.70977 \\
\hline Maximum & 48.58477 \\
\hline Minimum & -69.6695 \\
\hline $\begin{array}{l}\text { Standard } \\
\text { Deviation }\end{array}$ & 22.30708 \\
\hline Skewness & -0.8975 \\
\hline Kurtosis & 0.227672 \\
\hline Jarque-Bera & 73.26388 \\
\hline Prob. & $1.23 \mathrm{E}-16$ \\
\hline
\end{tabular}

FIGURE 2. Residual test of normality

\section{DISCUSSION}

The several factors that determined the changes in energy prices based on the changes in the agricultural sector (Piot-Lepetit \& M'Barek, 2011) were based on the imbalance between supply and demand of agricultural commodities (Roberts \& Schlenker, 2013). The imbalance between supply and demand has an immediate effect on prices (Schnepf, Resources, \& Division, 2005). The increasing demand for meat products in developing countries raises the demand for livestock cereal feeds. The increasing living standard and population of developing countries means to increase demand for imported meat (Resurreccion, 2004). Hence requiring more petroleum-based inputs (fertilizers, pesticides, and machinery) to produce more cereal for livestock feeds (Ward, Holden, White, \& Oldfield, 2016). Ethanol-extracted from sugar cane (Goldemberg, Coelho, \& Guardabassi, 2008) and corn replaced ether blended in
US conventional fuel resulting in the increased American production of ethanol (Crago, Khanna, Barton, Giuliani, \& Amaral, 2010). The increased demand for sugarcane and corn for biofuel exerted pressure on agricultural commodities prices (Gecan, Johansson, \& FitzGerald, 2009). Several countries imposed higher subsidies and import tariffs to prioritize the local biofuel market, which added pressure on agricultural commodities prices (de Gorter, 2014; Peters, Somwaru, Hansen, Seeley, \& Dirkse, 2009).

However, in terms of the supply side, the 4.6 billion hectares of agricultural land worldwide (Pimentel, 2003) for the past 50 years (1967-2017) has only increased slightly at 8 percent (Coulibaly, 2013). Moreover, over the same period, more agricultural lands were allocated in growing grains for animal feed (Pimentel, 2003), which require more petroleum-based inputs or biofuel production, reducing land for food production (Beckman, Borchers, \& Jones, 
2013). Also, the increasing world population and living standards drive prices (Southgate, 2009) at the same time added pressure on the energy sector to provide inputs for the agricultural commodities production (Pimentel, 2009). Several droughts hit the ability of major grain producers, reducing output and affecting world prices. In response, the farmers demand to increase electricity use, one-third above-normal year use, to draw underground water from lower water tables to provide irrigation. The situation in every succeeding drought is more difficult than the previous situation which worsens the problem (Fan, 2019).

\section{CONCLUSION}

This study investigated the deeper relationship between agriculture and energy price for the last four decades tracing the changes in the agriculture sector, which were not caused by the changes in the energy sector. The result of this study suggested that it was the changes in the price of agriculture that caused the price of energy to change attributed to the imbalance between supply and demand traceable to the high-protein diet of emerging economies, which required more energy-based inputs to produce. Also, the increasing biofuel demand and the distortion the global agricultural trade exerted pressure on the energy price. Finally, the severe droughts and flooding caused agriculture to increase energy demand to operate equipment that can cushion the impact of climate change. While most studies showed the rising energy prices changed, the relationship between the agriculture and energy sector and energy is both an input and output in the agriculture sector. This study affirmed that basically, the agriculture sector significantly shaped the energy sector and not the other way around.

\section{IMPLICATIONS}

This study attempted to quantify the causal relationship between energy and agricultural price using the structural economic framework that recognized the fundamental problem in the relationship between energy and agriculture. This study affirmed that basically, the agriculture sector significantly shaped the energy sector and not the other way around. Furthermore, this study presented a window of opportunity to closely examine the curious relationship between energy and agriculture prices.

\section{REFERENCES}

Abedin, J. (1985). Input demand and output supply elasticities for rice in Bangladesh: A study based on Thakurgaon farmers. The Bangladesh Development Studies, 13(3/4), 111-125.

Adelaja, A., \& Hoque, A. (1986). A multi-product analysis of energy demand in agricultural subsectors. Journal of Agricultural and Applied Economics, 18(2), 51-64. doi:https://doi.org/10.1017/S0081305200006105

Aha, B., \& Ayitey, J. Z. (2017). Biofuels and the hazards of land grabbing: Tenure (in) security and indigenous farmers' investment decisions in Ghana. Land Use Policy, 60, 48-59. doi:https://doi.org/10.1016/j.landusepol.2016.10.012

Akanni, K., \& Okeowo, T. (2011). Analysis of aggregate output supply response of selected food grains in Nigeria. Journal of Stored Products and Postharvest Research, 2(14), 266-278.

Alderman, H., \& Von Braun, J. (1986). Egypt's food subsidy policy: Lessons and options. Food Policy, 11(3), 223-237. doi:https://doi.org/10.1016/0306-9192(86)90007-2

Alier, J. M. (2009). Socially sustainable economic de-growth. Development and Change, 40(6), 1099-1119. doi:https:// doi.org/10.1111/j.1467-7660.2009.01618.x

Anderson, D. A., Burnham, K. P., Anderson, D., \& Burnham, K. P. (1998). Model selection and inference: A practical informationtheoretic approach. New York, NY: Springer-Verlag Telos.

Antle, J. M., Capalbo, S. M., Johnson, J. B., \& Miljkovic, D. (1999). The Kyoto protocol: Economic effects of energy prices on Northern plains dryland grain production. Agricultural and Resource Economics Review, 28(1), 96-105. doi:https:// doi.org/10.1017/S1068280500001015

Anwar, M. R., O'Leary, G., McNeil, D., Hossain, H., \& Nelson, R. (2007). Climate change impact on rainfed wheat in SouthEastern Australia. Field Crops Research, 104(1-3), 139-147. doi:https://doi.org/10.1016/j.fcr.2007.03.020

Arezki, R., Loungani, P., van der Ploeg, R., \& Venables, A. J. (2014). Understanding international commodity price fluctuations. California, CA: Elsevier.

Armstrong, D. S. (2002). Emotional distress and prenatal attachment in pregnancy after perinatal loss. Journal of Nursing Scholarship, 34(4), 339-345.

Asche, F., Khatun, F., et al. (2006). Aquaculture: Issues and opportunities for sustainable production and trade. Geneva, Switzerland: International Centre for Trade and Sustainable Development. 
Avalos, F. (2014). Do oil prices drive food prices? The tale of a structural break. Journal of International Money and Finance, 42, 253-271. doi:https://doi.org/10.1016/j.jimonfin.2013.08.014

Barrett, A., \& Trace, F. (1999). The impact of agricultural and forestry subsidies on land prices and land uses in Ireland. Retrieved from https://bit.1y/35i50eb (Accessed on 14 August, 2008)

Baumeister, C., \& Kilian, L. (2014). Do oil price increases cause higher food prices? Economic Policy, 29(80), 691-747. doi:https://doi.org/10.1111/1468-0327.12039

Baumeister, C., \& Kilian, L. (2016). Forty years of oil price fluctuations: Why the price of oil may still surprise us. Journal of Economic Perspectives, 30(1), 139-60. doi:https://doi.org/10.1257/jep.30.1.139

Beckman, J., Borchers, A., \& Jones, C. A. (2013). Agriculture's supply and demand for energy and energy products. USDA-ERS Economic Information Bulletin, 112(5), 45-60. doi:https://doi.org/10.2139/ssrn.2267323

Belardo, G. (2018). Trade diversification and changing food consumption patterns since the 2000s: The case of homogenizing diets globally and in the BRICS. Retrieved from https://bit.1y/2CX9WEo (Accessed on 16 August, 2017)

Bello, W. (2008). Manufacturing a food crisis. Nation New York, 286(21), 16-25.

Bergsten, C. F., \& Cline, W. R. (1982). Trade policy in the 1980s. New York, NY: Peterson Institute.

Bevan, M., \& Murphy, G. (1999). The small, the large and the wild: The value of comparison in plant genomics. Trends in Genetics, 15(6), 211-214. doi:https://doi.org/10.1016/S0168-9525(99)01744-8

Binswanger, H. (1989). The policy response of agriculture. The World Bank Economic Review, 3(1), 231-258. doi:https:// doi.org/10.1093/wber/3.suppl_1.231

Bond, M. E. (1987). An econometric study of primary commodity exports from developing country regions to the world. Staff Papers, 34(2), 191-227. doi:https://doi.org/10.2307/3867134

Box, T. W. (1974). Increasing red meat from rangeland through improved range management practices. Rangeland Ecology \& Management, 27(5), 333-336. doi:https://doi.org/10.2307/3896484

Brown, L. R. (1982). Global food prospects: Setting the record straight. Challenge, 25(5), 48-52. doi:https://doi.org/ 10.1080/05775132.1982.11470803

Bullock, J. B. (1984). Future directions for agricultural policy. American Journal of Agricultural Economics, 66(2), 234-239. doi:https://doi.org/10.2307/1241051

Butz, E. L. (1974). World protein markets: A supplier's view. Journal of the American Oil Chemists' Society, 51(1), 57A-58A. doi:https://doi.org/10.1007/BF02542091

Cachia, F. (2014). Regional food price inflation transmission (Working paper series No. ESS/14-01). FAO Statistics Division, New Jersy, NJ.

Cadenas, A., \& Cabezudo, S. (1998). Biofuels as sustainable technologies: Perspectives for less developed countries. Technological Forecasting and Social Change, 58(1-2), 83-103. doi:https://doi.org/10.1016/S0040-1625(97)00083-8

Carter, H. O., \& Youde, J. G. (1974). Some impacts of the changing energy situation on US agriculture. American Journal of Agricultural Economics, 56(5), 878-887. doi:https://doi.org/10.2307/1239014

Cathie, J. (1985). US and EEC agricultural trade policies: A long-run view of the present conflict. Food Policy, 10(1), 14-28. doi:https://doi.org/10.1016/0306-9192(85)90040-5

Chaudhuri, P. (1986). Aid and poverty 1. IDS Bulletin, 17(2), 14-21. doi:https://doi.org/10.1111/j.1759-5436.1986 .mp17002003.x

Cheamuangphan, A., Singhavara, M., \& Phaoumnuaywit, A. (2018). Cost and benefit analysis of rice production between transplanting and direct seeded method for rice in Upper Northern Region. International Journal of Business and Economic Affairs, 3(5), 227-236. doi:https://doi.org/10.24088/ijbea-2018-35005

Christensen, C. (2000). The new policy environment for food aid: The challenge of Sub-Saharan Africa. Food Policy, 25(3), 255-268. doi:https://doi.org/10.1016/S0306-9192(00)00005-1

Christensen, D., \& Heady, E. (1984). Impacts of energy price increases on the well-being of farmers and consumers. Energy System Policy, 8(3), 45-60. doi:https://doi.org/10.1016/j.foodpol.2010.10.003

Christiaensen, L. (2009). Revisiting the global food architecture: Lessons from the 2008 food crisis. Helsinki, Finland: World Institute for Development Economics.

Clay, E., \& Benson, C. (1990). Aid for food: Acquisition of commodities in developing countries for food aid in the 1980 s. Food Policy, 15(1), 27-43. doi:https://doi.org/10.1016/0306-9192(90)90022-R 
Coalition, G. F., Mesoamericano-CIMA, C. I., de Transgenicos, R. A. L. L., Colombia, R., Ambiental, A. I., Worldforests, P., ... de Reflexion Rural, S. G. (2006). Biofuels: A disaster in the making. Energy Bulletin, 13(6), 34-50.

Coelho, S. T. (2005). Biofuels advantages and trade barriers. In United Nations Conference on Trade and Development, Hague, Netherland.

Conceição, P., \& Mendoza, R. U. (2009). Anatomy of the global food crisis. Third World Quarterly, 30(6), 1159-1182. doi: https://doi.org/10.1080/01436590903037473

Cooper, R. N., Lawrence, R. Z., Bosworth, B., \& Houthakker, H. S. (1975). The 1972-75 commodity boom. Brookings Papers on Economic Activity, 1975(3), 671-723. doi:https://doi.org/10.2307/2534151

Coulibaly, A. L. (2013). The food price increase of 2010-2011: Causes and impacts. Paris, France: Library of Parliament Bibliothèque du Parlement.

Crago, C. L., Khanna, M., Barton, J., Giuliani, E., \& Amaral, W. (2010). Competitiveness of Brazilian sugarcane ethanol compared to US corn ethanol. Energy Policy, 38(11), 7404-7415. doi:https://doi.org/10.1016/j.enpol.2010.08.016

David, C. C., \& Balisacan, A. (1982). An analysis offertilizer policies in the philippines. Manila, Philippines: Philippine Institute for Development Studies.

de Gorter, H. (2014). Energy markets: The impact on trade in biofuels and farm goods. Retrieved from https://bit.1y/ 35hvf wp (Accessed on 15 July, 2016)

De Gorter, H., Drabik, D., \& Just, D. R. (2015). The economics of biofuel policies: Impacts on price volatility in grain and oilseed markets. New York, NY: Springer.

D'Ercole, R., \& Pigeon, P. (1998). Natural disasters in Bangladesh and South East Asia (Cambodia, Laos, Myanmar, the Philippines, Thailand, Vietnam): assessment and risks. Retrieved from https://bit.ly/345CEih

Dethier, J.-J., \& Effenberger, A. (2011). Agriculture and development: A brief review of the literature. New York, NY: The World Bank.

Dhillon, R., \& von Wuehlisch, G. (2013). Mitigation of global warming through renewable biomass. Biomass and Bioenergy, 48, 75-89. doi:https://doi.org/10.1016/j.biombioe.2012.11.005

Drabenstott, M. (1983). The 1980s: A turning point for US agricultural exports? Economic Review, 68(4), 3-15.

Duane, T. P. (2002). Regulation's rationale: Learning from the California energy crisis. Yale Journal, 19, 471.

Edwards, S. (1989). Exchange rate misalignment in developing countries. The World Bank Research Observer, 4(1), 3-21. doi:https://doi.org/10.1093/wbro/4.1.3

Elobeid, A. E., \& Tokgoz, S. (2006). Removal of US ethanol domestic and trade distortions: Impact on US and Brazilian ethanol markets (Technical report). Food and Agricultural Policy Research Institute, London, UK.

Esmaeili, A., \& Shokoohi, Z. (2011). Assessing the effect of oil price on world food prices: Application of principal component analysis. Energy Policy, 39(2), 1022-1025. doi:https://doi.org/10.1016/j.enpol.2010.11.004

Fan, S. (2019). Regional productivity growth in China's agriculture. Cambridge, MA: CRC Press.

Felix, D. (1985). How to resolve Latin America's debt crisis. Challenge, 28(5), 44-51. doi:https://doi.org/10.1080/05775132 .1985.11471044

Fleischer, S., \& Stibe, L. (1989). Agriculture kills marine fish in the 1980s: Who is responsible for fish kills in the year $2000 ?$ Ambio, 5(8), 347-350.

Food and Agriculture Organization. (1973). The state of food and agriculture 1973. Retrieved from https://bit.1y/ 32ZMnW1 (Accessed on 1 October, 1973)

Food and Agriculture Organization. (1983a). The state of food and agriculture, 1983. Retrieved from https://bit.1y/ $32 \mathrm{Zb} 5 \mathrm{Gd}$

Food and Agriculture Organization. (1983b). The state of food and agriculture, 1987-88. Retrieved from https://bit.ly/ 345ASO2

Food and Agriculture Organization. (1995). The state of food and agriculture, 1995. Retrieved from https://bit.1y/ 20wWHzJ

Gardner, B., Nuckton, C., et al. (1979). Factors affecting agricultural land prices. California Agriculture, 33(1), 4-6.

Gecan, R., Johansson, R., \& FitzGerald, K. (2009). The impact of ethanol use on food prices and greenhouse-gas emissions (Technical report). Congressional Budget Office, Washington, DC, WA. 
Gohin, A., \& Chantret, F. (2010). The long-run impact of energy prices on world agricultural markets: The role of macroeconomic linkages. Energy Policy, 38(1), 333-339. doi:https://doi.org/10.1016/j.enpol.2009.09.023

Goldemberg, J., Coelho, S. T., \& Guardabassi, P. (2008). The sustainability of ethanol production from sugarcane. Energy Policy, 36(6), 2086-2097. doi:https://doi.org/10.1016/j.enpol.2008.02.028

Gopalakrishnan, C., Koffi-Tessio, E. N., \& Khaleghi, G. H. (1985). Energy price increase and its impact on agricultural production: Evidence from Hawaii. Energy in Agriculture, 4, 179-188. doi:https://doi.org/10.1016/0167-5826(85)90015-4

Górka, J. (2016). Transforming payment systems in Europe. New York, NY: Springer.

Götz, L., Glauben, T., \& Brümmer, B. (2013). Wheat export restrictions and domestic market effects in Russia and Ukraine during the food crisis. Food Policy, 38, 214-226. doi:https://doi.org/10.1016/j.foodpol.2012.12.001

Griliches, Z. (1998). Productivity, R\&D, and the data constraint. In R\&D and productivity: The econometric evidence. New York, NY: University of Chicago Press.

Gunstone, F. (2011). Vegetable oils in food technology: Composition, properties and uses. New York, NY: John Wiley \& Sons.

Gustavsson, J., Cederberg, C., Sonesson, U., Van Otterdijk, R., \& Meybeck, A. (2011). Global food losses and food waste. Rome, Italy: Food and Agriculture Organization.

Hale, G., \& Nechio, F. (2012). Pricey oil, cheap natural gas, and energy costs. Economic Letter, 2012, 23-25.

Halila, M., Haddad, N., Sakr, B., \& Küsmenoglu, I. (2000). Region 5: Near East. In Linking research and marketing opportunities for pulses in the 21st century. New York, NY: Springer.

Hanegraaf, M. C., Biewinga, E. E., et al. (1998). Assessing the ecological and economic sustainability of energy crops. Biomass and Bioenergy, 15(4-5), 345-355.

Hanson, K., Robinson, S., \& Schluter, G. (1991). Sectoral effects of a world oil-price shock: Economy-wide linkages to the agricultural sector: Staff report (Technical report). Economic Research Service, Washington, DC, WA.

Haq, Z. U., \& Meilke, K. D. (2009). The role of income growth in emerging markets and the BRICs in agrifood trade (Working paper No. 48122). Canadian Agricultural Trade Policy Research Network, Tornoto, Canada.

Harl, N. E. (1985). The changing rural economy: Implications for rural America. New York, NY: Education Resources Information Center.

Hart, C. E., \& Babcock, B. A. (2000). Time for a new farmer-owned reserve? Retrieved from https://bit. ly/2XvHz9E (Accessed on 15 July, 2018)

Hazell, P. B. R., Jaramillo, M., \& Williamson, A. (1990). The relationship between world price instability and the prices farmers receive in developing countries. Journal of Agricultural Economics, 41(2), 227-241. doi:https://doi.org/ 10.1111/j.1477-9552.1990.tb00638.x

Headey, D. (2011). Rethinking the global food crisis: The role of trade shocks. Food Policy, 36(2), 136-146.

Heady, E. O. (1984). Economic impacts of energy prices on agriculture. New York, NY: Springer.

Heisey, P., \& Mwangi, W. (1997). Fertilizer use and maize production. Africa's emerging maize revolution (Working paper No. 7688). International Maize and Wheat Improvement Center, Mexico City, Mexico.

Horwich, G., \& Weimer, D. L. (1984). Oil-price shock: Market response and contingency planning (Technical report). American Enterprise Institution for Public Policy Research, Washington, DC, WA.

Jensen, G. R., \& Mercer, J. M. (2011). Commodities as an investment. New Jersy, NJ: Research Foundation of CFA Institute.

Joerin, J., \& Joerin, R. (2013). Reviewing the similarities of the 2007-08 and 1972-74 food crisis (Technical report). Swiss Federal Institute of Technology, Zurich, Germany.

Johnson, D. G. (1981). Food and agricultural policy for the 1980s. Books, 6(7), 45-56.

Jokiniemi, T., Mikkola, H., Rossner, H., Talgre, L., Lauringson, E., Hovi, M., \& Ahokas, J. (2012). Energy savings in plant production. Agronomy Research, 10(1), 85-96.

Just, R. E., \& Miranowski, J. A. (1993). Understanding farmland price changes. American Journal of Agricultural Economics, 75(1), 156-168. doi:https://doi.org/10.2307/1242964

Karsh, E., \& Rautsi, I. (1991). Why Saddam Hussein invaded Kuwait. Survival, 33(1), 18-30.

Karunagoda, K. (2004). Changes in labour market and domestic agriculture. Sri Lankan Journal of Agricultural Economics, $6(1), 82-97$.

Khakimyanov, M. I., \& Khusainov, F. F. (2016). Research energy consumption of well electric submersible pumps for oil production. International Journal of Business and Administrative Studies, 2(1), 1-5. doi:https://doi.org/10.20469/ 
ijbas.2.10001-1

Khan, M. A., Martin, P. L., \& Hardiman, P. (2003). California's farm labor markets: A cross-sectional analysis of employment and earnings in 1991, 1996, and 2001. New Dehli, India: Employment Development Department, Labor Market Information Division.

Khush, G. S. (1999). Green revolution: Preparing for the 21st century. Genome, 42(4), 646-655. doi:https://doi.org/ 10.1139/gen-42-4-646

Kloos, H. (1991). Peasant irrigation development and food production in Ethiopia. Geographical Journal, 10(1), $295-306$. doi:https://doi.org/10.2307/635503

Koizumi, T. (2013). Biofuel and food security in China and Japan. Renewable and Sustainable Energy Reviews, 21, $102-109$. doi:https://doi.org/10.1016/j.rser.2012.12.047

Kovarik, B., \& Singh, B. (2013). Biofuels in history. Biofuel Crops: Production, Physiology and Genetics, 5(7), 1-22. doi: https://doi.org/10.1079/9781845938857.0001

Krugman, P. (1983). Oil shocks and exchange rate dynamics. In Exchange rates and international macroeconomics. Chicago, IL: University of Chicago Press.

Labys, W. C., \& Perrin, Y. (1976). Multivariate analysis of price aspects of commodity stabilization. Weltwirtschaftliches Archiv, 112(3), 556-564. doi:https://doi.org/10.1007/BF02696817

Lanne, M., \& Lütkepohl, H. (2010). Structural vector autoregressions with nonnormal residuals. Journal of Business \& Economic Statistics, 28(1), 159-168. doi:https://doi.org/10.1198/jbes.2009.06003

Latruffe, L., \& Le Mouël, C. (2009). Capitalization of government support in agricultural land prices: What do we know? Journal of Economic Surveys, 23(4), 659-691. doi:https://doi.org/10.1111/j.1467-6419.2009.00575.x

Leech, G. (2006). Crude interventions: The United States, oil and the new world dis-order. London, UK: Zed books.

Lockeretz, W. (1983). Energy price increases: How strong an incentive for decreasing energy use in agriculture? Biological Agriculture \& Horticulture, 1(4), 255-267. doi:https://doi.org/10.1080/01448765.1983.9754405

Lofman, D., Petersen, M., \& Bower, A. (2002). Water, energy and environment nexus: The California experience. International Journal of Water Resources Development, 18(1), 73-85. doi:https://doi.org/10.1080/07900620220121666

Longmire, J. L., \& Morey, A. (1983). Strong dollar dampens demand for US farm exports (Technical report). United States Department of Agriculture, Economic Research Service, Wahsington, DC, WA. doi:https://doi.org/10.1016/S0301 $-4215(97) 00048-7$

Lunnan, A. (1997). Agriculture-based biomass energy supply: A survey of economic issues. Energy Policy, $25(6), 573-582$.

Massad, C. (1986). Alleviation of the debt burden: Historical experience and present need. Cepal Review, 3(6), 45-50. doi:https://doi.org/10.18356/00ba838e-en

McCouch, S., Baute, G. J., Bradeen, J., Bramel, P., Bretting, P. K., Buckler, E., ... Cole, G. (2013). Agriculture: Feeding the future. Nature, 499(7456), 23-40. doi:https://doi.org/10.1038/499023a

Meshcherskaya, A. V., \& Blazhevich, V. (1997). The drought and excessive moisture indices in a historical perspective in the principal grain-producing regions of the former Soviet Union. Journal of Climate, 10(10), 2670-2682. doi:https:// doi.org/10.1175/1520-0442(1997)010<2670:TDAEMI>2.0.CO;2

Miranowski, J. A. (1979). Effects of energy price rises, energy constraints, and energy minimization on crop and livestock production activities. Journal of Production, 1(1), 5-14. doi:https://doi.org/10.2307/1349311

Mohajan, H. (2013). Global food price hike is a burden to the poor. Retrieved from https://bit.1y/2D1F8Cw (Accessed on 16 August, 2017)

Năstase, L. L. (2012). Trade in goods of the European Union with the BRICS countries. Annals of the University of Craiova, Economic Sciences Series, 13(5), 23-40.

Nazlioglu, S., \& Soytas, U. (2012). Oil price, agricultural commodity prices, and the dollar: A panel cointegration and causality analysis. Energy Economics, 34(4), 1098-1104. doi:https://doi.org/10.1016/j.eneco.2011.09.008

New York Times. (1977). Farmers. Retrieved from https ://nyti.ms/2KCMMHE (Accessedon 15 March, 2009)

Nonhebel, S. (2012). Global food supply and the impacts of increased use of biofuels. Energy, 37(1), 115-121. doi:https:// doi.org/10.1016/j.energy.2011.09.019

Nonhebel, S., \& Kastner, T. (2011). Changing demand for food, livestock feed and biofuels in the past and in the near future. Livestock Science, 139(1-2), 3-10. doi:https://doi.org/10.1016/j.livsci.2011.03.021 
Peters, M., Somwaru, A., Hansen, J. M., Seeley, R., \& Dirkse, S. (2009). Modeling biofuels expansion in a changing global environment. In Conference International Association of Agricultural Economists, Beijing, China.

Pfaffenzeller, S., Newbold, P., \& Rayner, A. (2007). A short note on updating the grilli and yang commodity price index. The World Bank Economic Review, 21(1), 151-163. doi:https://doi.org/10.1093/wber/lhl013

Pimentel, D. (2003). Technology and natural resources. Perspectives in Resource Management in Developing Countries, 4(5), 401-420.

Pimentel, D. (2009). Energy inputs in food crop production in developing and developed nations. Energies, 2(1), 1-24. doi:https://doi.org/10.3390/en20100001

Piot-Lepetit, I., \& M'Barek, R. (2011). Methods to analyse agricultural commodity price volatility, In Methods to analyse agricultural commodity price volatility. New York, NY: Springer. doi:https://doi.org/10.1007/978-1-4419-7634-5_1

Pollak, J. (2010). California water and the rhetoric of crisis. Berkeley Planning Journal, 23(1), 45-50. doi:https://doi.org/ $10.5070 /$ BP32318173

Popkin, J. (1974). Commodity prices and the US price level. Brookings Papers on Economic Activity, 1974(1), 249-259. doi:ttps://doi.org/10.2307/2534079

Quddus, M., Becker, C., et al. (2000). Speculative price bubbles in the rice market and the 1974 Bangladesh famine. Journal of Economic Development, 25(2), 155-175.

Ramcharran, H. (2002). Oil production responses to price changes: An empirical application of the competitive model to OPEC and non-OPEC countries. Energy Economics, 24(2), 97-106. doi:https://doi.org/10.1016/S0140-9883(01) 00091-3

Resurreccion. (2004). Sensory aspects of consumer choices for meat and meat products. Meat Science, 66(1), 11-20. doi: https://doi.org/10.1016/S0309-1740(03)00021-4

Roberts, M. J., \& Schlenker, W. (2013). Identifying supply and demand elasticities of agricultural commodities: Implications for the US ethanol mandate. American Economic Review, 103(6), 2265-95. doi:https://doi.org/10.1257/aer.103.6 .2265

Rosegrant, M. W. (2008). Biofuels and grain prices: Impacts and policy responses. Washington, DC, WA: International Food Policy Research Institute.

Roser, M., \& Ritchie, H. (2018). Fertilizer and pesticides: Our world in data. Retrieved from https ://bit. ly/201dgoe

Schmitz, A., \& Moss, C. B. (2015). Mechanized agriculture: Machine adoption, farm size, and labor displacement. Ag Bio Forum, 18(3), 278-296.

Schnepf, R. D., Resources, S., \& Division, I. (2005). Price determination in agricultural commodity markets: A primer. In Congressional Research Service, Library of Congress, Washington, DC, WA.

Schwert, G. W. (2002). Tests for unit roots: A Monte Carlo investigation. Journal of Business \& Economic Statistics, 20(1), 5-17. doi:https://doi.org/10.1198/073500102753410354

Sebri, M., \& Ben-Salha, O. (2014). On the causal dynamics between economic growth, renewable energy consumption, $\mathrm{CO}_{2}$ emissions and trade openness: Fresh evidence from BRICS countries. Renewable and Sustainable Energy Reviews, 39, 14-23. doi:https://doi.org/10.1016/j.rser.2014.07.033

Shane, M., \& Liefert, W. M. (2007). Weaker dollar strengthens US agriculture. Retrieved from https://bit.ly/2KHzsSh (Accessed on 15 July, 2015)

Sharma, S., \& Singer, H. W. (1989). Economic development and world debt. New York, NY: Springer.

Shipton, P. (1990). African famines and food security: Anthropological perspectives. Annual Review of Anthropology, 19(1), 353-394.

Sidhu, S. S., \& Mudahar, M. S. (1999). Privatization and deregulation: Needed policy reforms for agribusiness development. New York, NY: Springer Science \& Business Media.

Singer, H. W. (1989). The 1980s: A lost decade development in reverse? In Growth and external debt management. New York, NY: Springer.

Soesastro, M. H. (1989). The political economy of deregulation in Indonesia. Asian Survey, 29(9), 853-869. doi:https:// doi.org/10.1525/as.1989.29.9.01p0304h

Sorda, G., Banse, M., \& Kemfert, C. (2010). An overview of biofuel policies across the world. Energy Policy, 38(11), 6977-6988. doi:https://doi.org/10.1016/j.enpol.2010.06.066 
Southgate, D. (2009). Population growth, increases in agricultural production and trends in food prices. The Electronic Journal of Sustainable Development, 1(3), 41-50.

Sovacool, B. K. (2009). Rejecting renewables: The socio-technical impediments to renewable electricity in the United States. Energy Policy, 37(11), 4500-4513. doi:https://doi.org/10.1016/j.enpol.2009.05.073

Stout, L., Stout, B., Myers, C., Hurand, A., \& Faidley, L. (1979). Energy for world agriculture. Rome, Italy: Food \& Agriculture Org.

Streeten, P. (2016). What price food?: Agricultural price-policies in developing countries. New York, NY: Springer.

Talbot, R. B., \& Moyer, H. W. (1987). Who governs the Rome food agencies? Food Policy, 12(4), 349-364. doi:https://doi.org/ 10.1016/0306-9192(87)90007-8

Taylor, J., \& VanDoren, P. (2002). California's electricity crisis. In Electricity pricing in transition. New York, NY: Springer.

Thapinta, A., \& Hudak, P. F. (2000). Pesticide use and residual occurrence in Thailand. Environmental Monitoring and Assessment, 60(1), 103-114. doi:https://doi.org/10.1023/A:1006156313253

Trostle, R. (2010). Global agricultural supply and demand: Factors contributing to the recent increase in food commodity prices. Darby, PA: Diane Publishing.

Wagenmakers, E. (2003). Model selection and multimodel inference: A practical information-theoretic approach. San Diego, CA: Academic Press.

Ward, S. M., Holden, N. M., White, E. P., \& Oldfield, T. L. (2016). The "circular economy" applied to the agriculture (livestock production) sector discussion paper. In Workshop on the Sustainability of the EU's Livestock Production Systems, New Jersy, NJ.

Watt, M. (1984). An energy analysis of the Australian food system. Energy in Agriculture, 3, 279-288. doi:https://doi.org/ 10.1016/0167-5826(84)90036-6

Westelius, N. J. (2005). Discretionary monetary policy and inflation persistence. Journal of Monetary Economics, 52(2), 477-496. doi:https://doi.org/10.1016/j.jmoneco.2004.05.006

Whittlesey, N. K., \& Lee, C. (1975). An empirical analysis of the impacts of energy price changes on food costs. In Proceedings, Annual Meeting Western Agricultural Economics Association, Milwaukee, WI.

Wik, M., Pingali, P., \& Brocai, S. (2008). Global agricultural performance: Past trends and future prospects. Citeseer. Retrieved from https://bit.1y/35kkrh7 (Accessed on 15 June, 2018)

Wilhite, D. A., \& Glantz, M. H. (1985). Understanding: The drought phenomenon and the role of definitions. Water International, 10(3), 111-120. doi:https://doi.org/10.1080/02508068508686328

Wilson, T. L. (1997). Consumer prices for energy and food accelerated in 1996. Monthly Lab Review, 120, 36.

World Bank. (2016). World bank commodity price data. Retrieved from https://bit.ly/2rTC091 (Accessed on 15 July, 2018)

Yoshino, N., \& Alekhina, V. (2016). Impact of oil price fluctuations on an energy-exporting economy: Evidence from Russia. Journal of Administrative and Business Studies, 2(4), 156-166. doi:https://doi.org/10.20474/jabs-2.4.2 